\title{
Fiscal Policy and Economic Performance: A Review
}

\author{
George E. Halkos* and Epameinondas A. Paizanos
}

\author{
Laboratory of Operations Research, Department of Economics, University of Thessaly, Volos, Greece
}

\begin{abstract}
The economic implications of government expenditure have been shown to be significant and broad. In particular, government spending has been shown to enhance long-run economic growth by increasing the level of human capital and Research and Development (R\&D) expenditure, and by improving public infrastructure. On the other hand, there is evidence that a greater size of government spending may be less efficient and therefore not necessarily associated with a better provision of public goods and higher levels of economic growth. Moreover, it is likely that the size of government expenditure and its composition are associated with key aspects of the quality of growth, such as income inequality and environmental sustainability. This paper presents a review of the theoretical and empirical literature on the relationship between fiscal policy and economic activity, both in terms of long-run economic growth and short-term output fluctuations. In general, empirical evidence on these relationships is not robust and remains inconclusive.
\end{abstract}

Keywords: Fiscal policy, Economic growth, Government Expenditure, Taxation.

\section{INTRODUCTION}

Nowadays, in most countries a large part of Gross Domestic Product (GDP) is being spent through government consumption and investment. In particular, the share of government expenditure in GDP increased in most developed countries during the period 19701995, in an attempt to alleviate the effect of business cycles and achieve income equality. This trend reverted during the period $1995-2005$, in order to confine increasing public debt ratios, but subsequently increased again, as several governments have followed expansionary macroeconomic policies to support and expedite the recovery of their economies in response to the economic crisis that initiated in 2008. Despite renewed recent attempts to reduce government expenditure, still an average of more than $45 \%$ of GDP is spent by governments and the economic implications of government expenditure have been shown to be significant and broad.

Bergh and Henrekson (2011) identify three main analytical frameworks through which the determinants of growth, including fiscal policy, have been analysed in the literature, namely neoclassical growth models, endogenous growth theory and a third strand of literature that emphasizes the role of institutions. In neoclassical growth theory, fiscal policy can only have a temporary effect on growth and in the long-term the economy grows at the exogenously determined rate of technological progress, which in the long run should be comparable in all countries (Solow, 1956; Swan, 1956; Cass, 1965; Koopmans, 1965). This issue is important

*Address correspondence to this author at the Laboratory of Operations Research, Department of Economics, University of Thessaly, Volos, Greece; Tel: +30 24210 74920; Fax: +30 24210 74772; E-mail: halkos@econ.uth.gr JEL Classification: E62; O47; O44; Q01; Q56; H5; H2.

E-ISSN: 1929-7092/16 since in case of comparable long term growth rates among countries, the long run effects of fiscal policy are less significant (Gwartney, et al. 1998).

However, many theoretical studies have shown that there are several mechanisms that justify significantly different growth rates among economies (Lucas, 1988; Romer, 1990), which is also confirmed by empirical evidence (Quah, 1996; Gwartney and Lawson, 1997). Endogenous growth theory specifies no diminishing returns in the production function and thus, any factor that affects the level of technology also affects the long-term growth rate of the economy (Romer, 1986; Barro, 1990; Rebelo, 1991). Psarianos (2002) identifies three main distortions that may lead to a sub-optimal steady state rate of growth of output by the decentralized allocation of resources in this framework, as follows: (a) A weakening of the incentive to invest in R\&D due to the probability of monopoly rents that reward successful innovators not being realized, (b) The inefficient allocation of capital goods in the production process due to the monopolistic pricing of those goods, and (c) The inability of the market to reward researchers for the reduction in the cost of future technological advancements that follows the expansion of current knowledge. Therefore, there is room for fiscal policy to induce the private economy to attain the socially optimal outcomes by corresponding subsidies to alleviate the aforementioned market failures, albeit at the cost of facing a time-inconsistency problem ${ }^{1}$. The significance of institutions on economic growth was initially highlighted by North $(1987,1991)$ and was empirically asserted by several studies (for example, Acemoglu et al., 2002; Dawson, 2003; Rodrik

${ }^{1}$ For details see Psarianos (2009).

〔C 2016 Lifescience Global 
et al. 2004; Berggren and Jordahl, 2005; Glaeser et al. 2004).

Furthermore, most macroeconomic models consent that an expansionary monetary policy is characterized by a decrease of the interest rate and is associated with a boost in growth and inflation while, at the same time, the majority of empirical evidence is consistent with this statement (Perotti, 2007). However, there is no such consensus as regards the effects of an expansionary fiscal policy. For instance, neoclassical models suggest that real wage and private consumption will decline, while neo-Keynesian models suggest an opposite effect.

The remainder of the paper is structured as follows: Section 2 presents the theoretical underpinnings and the empirical findings of the literature on the link between fiscal policy and long-term economic growth, while Section 3 does the same for the relationship between fiscal policy and short-term output fluctuations. Finally, Section 4 provides conclusions and directions for future research.

\section{HOW THE GOVERNMENT SIZE AFFECTS LONG- TERM ECONOMIC GROWTH}

\subsection{Factors that Encourage Long-Run Growth}

The main analytical tool used to examine the effects of fiscal policy on economic growth is the endogenous growth theory. According to Lopez et al. (2010) and IMF (2015), endogenous growth theory identifies four main mechanisms through which government expenditure and tax reforms may increase long-run growth, as follows:

\section{Physical Capital}

Government spending being targeted at efficient public investments, like expenditure on infrastructure, may improve the productivity of the private sector and therefore, increase the rate of return on private investment both at the corporate and individual level. This increase in productivity leads to the increase of the long-term rate of growth (Nourzad and Vrieze, 1995; Sanchez-Robles, 1998). On the government revenues side, tax-cuts on capital income may increase savings and investments, and therefore enhance longrun growth (Rebelo, 1991; Devereux and Love, 1994).

\section{Human Capital}

Economists have long pointed out the importance of human capital as one of the main determinants of longterm growth (Lucas, 1988; Mankiw et al., 1992; Barro, 2001). In particular, human capital accumulation increases growth directly as input in production processes, as implied by the neoclassical models, but also indirectly by promoting ideas and thus inducing technological progress (Jones, 2001). In the presence of positive externalities and market failures, in order to provide the optimal level of education and health, government expenditure (Guellec and van Pottelsberghe, 1999) and appropriate reformation of the tax-system (King and Rebelo, 1990; Pecorino, 1993) may support the accumulation of human capital. This may in turn increase the productivity of the private sector and therefore encourage economic growth as shown by several theoretical and empirical works.

\section{Total Factor Productivity}

Public investment has the potential to boost private sector factor productivity, as it has been shown by both neoclassical (Barro, 1990; Glomm and Ravikumar, 1994; Turnovsky and Fisher, 1995) and endogenous (Baier and Glomm, 2001) growth models. In the presence of positive externalities from R\&D and dissemination of ideas, there is an important role for governments which can alleviate market failures, increase total factor productivity and ultimately enhance long-run growth. In particular, government expenditure on infrastructure and services, like $R \& D$, national defense and transportation system can directly enhance private sector productivity and support technological advancements while government provision of public goods such as education and health can improve the diffusion and use of new technologies. On the tax revenues side, appropriate tax reforms can provide incentives to encourage private $R \& D$ expenditure.

\section{Labor Supply}

Several studies in the framework of endogenous growth theory examined the mechanisms through which fiscal policies may increase labor supply and enhance long-run growth (Devereux and Love, 1994; Turnovsky, 2000). Individual decisions on whether to participate in the labor market (extensive response) and how much to work (intensive response) are largely influenced by the tax-benefit system. Recent empirical works provide evidence that the influence of the tax system on these decisions is greater for specific groups, such as older workers and women and at the lower end of the income distribution (OECD, 2011).

\subsection{Factors Harmful for Long-Run Growth}

On the other hand, as the size of the government grows, an increasing number of resources are 
progressively allocated by political rather than market mechanisms. Eventually, the enhancing effect of government size on long-term growth is expected to diminish and ultimately become negative. Gwartney et al. (1998) schematize these factors as follows:

\section{Diminishing Returns of Government Expenditure}

As government grows compared to the private sector, the law of diminishing returns impoverishes the reinforcing effect of government expenditure on economic growth. At small levels of government size, government expenditure is targeted at fundamental functional categories such as the insurance of law and order, as well as the provision of national defense and protection of property rights, which encourage private sector efficiency and stimulate long-run growth ${ }^{2}$. Nevertheless, governments may further enhance economic growth by expanding their provision to several other functions. For instance, government expenditure on public goods like transportation infrastructure, education and health further encourage economic growth by alleviating market failures and increasing total factor productivity. However, if government expenditure continues to increase it is progressively targeted to gradually less productive and efficient activities, which could be more efficiently provided by the private sector. Therefore, such an improvident expansion of government is associated with negative returns and therefore hinders long-run growth.

\section{Disincentive Effects of Higher Taxation and Government Borrowing}

As the level of government expenditure grows, higher tax-revenues and greater borrowing are required to finance it. A greater tax rate on the corporate level reduces the investment rate of return and therefore fewer risks and investment projects are undertaken by the private sector, eventually lowering private sector productivity (Browning, 1976). On the individuals' side, higher levels of labor income tax reduce the income of workers, distort their incentives to participate in the labor market and therefore reduce labor supply. Moreover, more borrowing by the government can crowd out private investment by increasing the interest rate and lead to higher tax-rates in the future. As a

\footnotetext{
${ }^{2}$ In particular, spending on defence may stimulate economic output through a Keynesian increase in aggregate demand but may also hinder growth mainly through the crowding-out of investment or a reduction in public spending in other functional categories such as expenditure in infrastructure (Kollias et al., 2007; Kollias and Paleologou, 2010).
}

result, progressively more resources are allocated to the public sector and even in the case that there were no diminishing returns of government spending these factors would have an alleviating effect on long-term growth.

\section{Slowing of the Wealth-Creation Process}

Joseph Schumpeter (1942) described as "creative destruction" the process of punishment by competition of those who do not succeed in combining the available resources in an efficient way during production. In the private sector, driven by their efforts to maximize profits, decision-makers have great incentives to keep cost low, combine the production factors in the most efficient way and absorb improved new technologies rapidly. In this sense, the political system is significantly less dynamic than free markets, since adjustment to new opportunities and adoption of better technologies occurs at a much slower rate in the public sector. This is a significant inadequacy of governments, as this inflexibility is a key detrimental factor of long-run growth.

Figure 1 depicts the related hypothesis that the relationship between the growth rate and the size of government is an inversely U-shaped curve, known as the Armey curve (Armey, 1995). At very small levels of government size, depicted on the horizontal axis, as government expands from zero (complete anarchy), the economy growth-rate initially increases up to a threshold point B. However, as government size further expands, spending is targeted at less productive functions, which at some point begin to dominate the positive effects and consequently reduce the rate of economic growth, eventually rendering it negative at levels of government where expenditure is channeled to counterproductive activities. Moreover, it should be highlighted that in case of governments which do not undertake activities solely based on their rate of return, the curve is downwards shifted, thereby further deterring the growth capabilities of the economy.

\subsection{Empirical Literature Review}

The previous discussion of the mechanisms through which government expenditure and taxes affect economic growth suggests that this effect is ambiguous in the relevant literature. This section classifies the main empirical studies on the relationship between fiscal policies and long-term growth and briefly presents their methodology and results. 


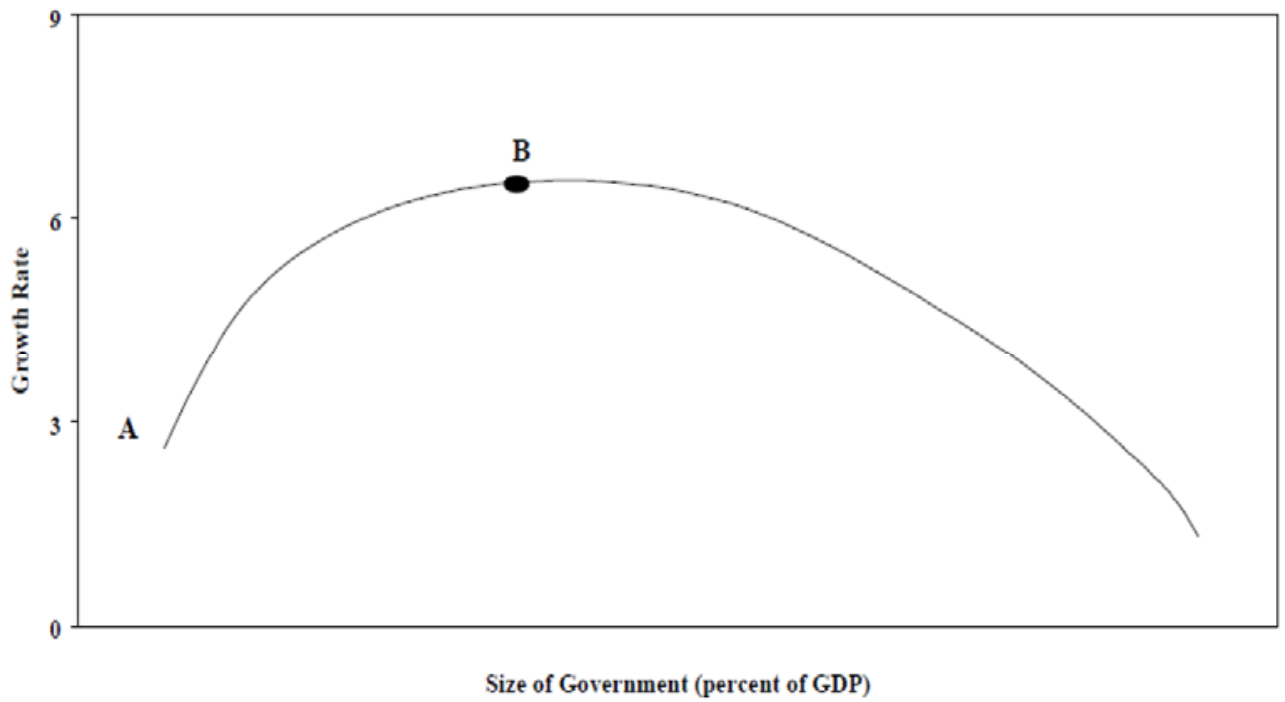

Figure 1: The size of government-growth curve.

Source: Gwartney et al. (1998, p. 5).

\section{Government Expenditure and Economic Growth}

Early works concentrated on the effect of total government expenditure on economic growth. In this regard, several studies report a significantly negative impact of the share of government expenditure on growth rates, in line with the hypothesis that smaller governments are associated with greater economic growth rates. Grier and Tullock (1989) analyzed a sample of 115 countries, using data averaged over 5year periods and found a significantly negative effect of the government share of GDP on the growth of real GDP, however, most of the relation was based on the 24 OECD countries sub-sample in their research. In a couple of related studies, Landau (1983, 1986) examined cross-section data on 104 countries, controlling for education and energy consumption, and reported a negative impact of government consumption expenditure on the growth rate of per capita GDP.

Marlow (1986) studied a sample of 19 developed countries over the period 1960-1980, controlling only for the level and growth of government expenditure and argued that a larger public sector harms long-term growth. A dataset of 23 OECD countries, as well as a more representative sample of 60 countries was examined by Gwartney et al. (1998) who provided evidence on the existence of a robust negative effect of government expenditure on economic growth, even after the effects of education, investment, institutional quality and macroeconomic stability were taken into account. Other important works that also report a robust negative effect of government size on economic growth include Barro (1991) and Bajo-Rubio (2000).
On the other hand a few studies have suggested a positive relationship between government size and long-term growth. Ram (1986), examining a sample of 115 countries for the period 1960-1980 reported that the effect of government expenditure on growth is significantly positive while he provided evidence that total factor productivity is greater in the public sector. However, it is likely that the results of this study are influenced by endogeneity, since greater growth rates are associated with an increase in government expenditure, although Ram (1989) failed to reject the hypothesis of exogeneity using Hausman tests (Engen and Skinner, 1992). In a more recent study, Colombier (2009) applied the M-estimator of Yohai et al. (1991) and reported a positive effect of government expenditure on the growth rate of OECD countries. However, Bergh and Ohrn (2011) suggest that these estimates are driven by the unique dataset and specification used ${ }^{3}$. Finally, several other studies have suggested the existence of a positive relationship between government expenditure and economic growth (for example, Ghali, 1998 and Dalamagas, 2000).

Furthermore a considerable number of studies have provided inconclusive evidence regarding the impact of government size on economic growth. An early work by Cameron (1982), based on cross-sectional data, found that the effect of share of government spending over GDP on economic growth was negative, although very

\footnotetext{
${ }^{3}$ For details see Bergh and Henrekson (2011).
} 
weak. Levine and Renelt (1992) stressed the importance of following an appropriate specification, since they found that the estimated effects were not robust to the inclusion of different control variables. Dowrick (1993) incorporated technological growth in the Ram (1989) model and reported evidence of endogeneity of the government expenditure variable and therefore no evidence of a significant effect of government spending on economic growth. Other studies that report no evidence of a significant relationship between government spending and economic growth are Kormendi and Meguire (1985) and Sala-i-Martin (1997).

\section{Taxation and Economic Growth}

In general, the effect of taxes on economic growth is less ambiguous in the empirical literature, since it is reported to be significantly negative in the majority of studies. Koester and Kormendi (1989) examined cross sectional data and reported that, controlling for average tax rates, the marginal tax rate has a significant negative impact on economic growth. In a related study, King and Rebelo (1990), based their analysis on endogenous growth theory and reported that an increase in the tax rate is associated with a reduction of long-term economic growth. Moreover, Devereux and Love (1994) suggested that an overall drop in tax rates significantly improves the growth rate, while Turnovsky (2000) reported that an increase in capital income tax is associated with a substantial reduction of economic growth. On the other hand, Lucas (1990) and Turnovsky (2004) did not find a significant effect of the tax rate on growth, a result that may be attributed to their assumptions of inelastic labor supply and existence of no human capital, respectively. Finally, Koester and Kormendi (1989) reported that marginal tax rates have a significant negative relationship with the level of per capita GDP only and not with economic growth.

\section{Factors that Influence the Effect of Government Size on Economic Growth}

Many studies have stressed the role of a number of factors that can influence the magnitude and significance of the effect of government size on economic growth. These determinants comprise the composition of government expenditure and taxation, the volatility of fiscal spending, the creation of fiscal deficits, the level of economic development, the initial size of government intervention and the quality of institutions.
The Composition of Government Expenditure and Taxation

The composition of government expenditure and taxation is an important factor of fiscal policy, since the different components of spending and type of taxes imposed may have very different implications on longterm growth. Barth and Bradley (1987), in an early study, examined 16 OECD countries during the period 1971-1983 and found a negative effect of government consumption spending on the growth rate, while the effect of government investment spending was positive, though insignificant. In a couple of related studies, Aschauer $(1988,1989)$ pointed out the importance of government capital accumulation and reported a positive effect on productivity growth, while the associated effect of government consumption was weaker.

The significant effect of government spending on education and health, public expenditure on infrastructure, as well as the role of R\&D expenditure, has been well documented in the relevant literature (Lucas, 1988; Barro, 1990; Romer; 1990; Jones et al. 1993; Hansson and Henrekson, 1994; Agenor and Neanidis, 2006). Thus, the effect of government expenditure on long-term growth can be enhanced if it supports the accumulation of infrastructure that can be used as production factors in the private sector (Devarajan et al. 1996). Turning our attention to more recent studies, Bleaney et al. (2001) and Romero-Avila and Strauch (2008), reported that government consumption expenditure and spending on social welfare do not affect the rate of growth, whereas public investment has positive effects.

On the government revenues side, Easterly and Rebelo (1993a, 1993b) suggested that only income tax rates have a negative relationship with long-term growth, while other tax measures have no significant effect. Kneller et al. (1999) argued that the reinforcing effect of government investment expenditure is significant only when financed by non-distorting taxes and at relatively small size of government, while a rise in distorting taxes is associated with lower levels of long-term growth. Similar findings that direct, rather that indirect, taxation alleviates economic growth have been reported in more recent studies, such as these by Padovano and Galli (2002a, 2002b), Widmalm (2001), Lee and Gordon (2005) and Bergh and Ohrn (2011). Finally, Chen and Lu (2013) examined the effects of the rate of capital income and labour income tax rates and reported a negative relationship with economic growth for both types. 


\section{The Volatility of Fiscal Spending}

Fiscal volatility also constitutes a significant issue concerning the effect of fiscal policy on economic growth. According to Afonso and Furceri (2010), economic theory suggests that government spending volatility may have either a positive or negative effect on private investment and economic growth, based on how it affects business-cycle volatility. A positive effect on growth is associated with the capacity of fiscal policy to alleviate fluctuations of the business cycle and smooth economic fluctuations by the use of automatic stabilizers. On the other hand, if fiscal policy is characterized by the use of pro-cyclical measures, it may exacerbate the fluctuation of the business-cycle and thus reduce long-term growth (Fatas and Mihov, 2003; Lane 2003).

\section{The Role of Fiscal Deficits}

Fiscal deficits may influence the level of savings in the economy and eventually, depending on the assumptions made, may have a significant or no impact on economic growth (Gray et al., 2007). In neoclassical growth theory, even if fiscal deficit reduces savings, it has no long-term impact on economic growth, despite causing a lower capital to labor ratio and ultimately increasing the interest rate and reducing the level of real wages. On the other hand, endogenous growth theory predicts a more persistent effect of the savings rate on long-term growth. Empirical evidence provides ambiguous results regarding the sign and significance of this effect.

Fisher (1993) suggested that fiscal deficits have a negative relationship with economic growth by reducing both capital accumulation and private sector productivity growth. Adam and Bevan (2005) argued that the impact of fiscal deficit on growth rate may depend on the initial size of the deficit as well as the source that is used to finance it. In particular, deficits can: reinforce growth if financed by limited seigniorage; deter growth if financed by domestic debt; be growth enhancing if financed by external loans at market rates. On the other hand, Taylor et al. (2011) suggested that there is a significant positive effect of a higher primary deficit on economic growth, even after controlling for the increase of the interest rate.

\section{The Level of Economic Development}

As already mentioned, Wagner's law suggests that the size of government is typically smaller in developing countries. Bergh and Henrekson (2011) took this relationship one step further and argued that the effect of government size on economic growth is positive in poor countries. For example, Besley and Persson (2009) suggested that in developing countries there is a positive relationship between tax revenues and economic growth since at low levels of taxation only the most fundamental functions of government intervention, such as the protection of property rights, are implemented. In more developed countries, where tax revenues are higher, organized interest groups attempt to receive advantages for themselves and rentseeking activities are larger, leading to market failures and eventually harming economic growth (Bergh and Henrekson, 2011; Buchanan, 1980; Olson, 1982).

However, empirical evidence on the relationship of government size and economic growth in developing countries is inconclusive. Miller and Russek (1997) reported negative effects of taxes on growth in OECD countries but positive effect for developing countries. On the other hand, Aslund and Jenish (2006) found that in developing countries there is a negative relationship between government expenditure and economic growth in recent years. Finally, many studies report an insignificant effect of government size on long-term growth in developing countries (Nelson and Singh, 1998; Campos and Coricelli, 2002; Beck and Laeven, 2005).

\section{The Optimal Size of Government}

As mentioned, the Armey curve developed by Armey (1995) exhibits that there is a non-linear relationship between government size and economic growth. In particular, this theory suggests that for small levels of government an increase in public expenditure may promote economic growth, however when the size of government exceeds a certain threshold the impact of a government spending expansion becomes negative. The foundation for this theory is that in countries where the size of government is large the share of public expenditures that is beneficial for private market productivity is typically smaller than in countries where the size of government is relatively small (Folster and Henrekson, 2001). Afonso and Furceri (2010) identify two early studies (Slemrod, 1995; Tanzi and Zee, 1997) that find a negative impact of government expenditure on economic growth when the size of government exceeds a certain threshold.

Focusing on the US economy, Grossman (1987) found that the level of government expenditures in 1983 exceeded by $87 \%$ the level that would maximize the private sector productivity and suggested that 
output could be significantly enhanced by reducing government expenditure and using the spare labour in the private sector. Moreover, Peden (1991) found that the optimal size of government expenditures in the US economy is about $17-20 \%$ of GNP, far less than the $35 \%$ observed in 1986 (Chobanov and Mladenova, 2009). In a related study, Chen and Lee (2005), examined economic growth in Taiwan and reported that all classifications of government size have a threshold effect and that a non-linear relationship of the Armey curve exists. Finally, Davies (2008), using panel data analysis, suggested that the optimal size of government with respect to economic performance is considerably smaller than the optimal size of government with respect to broader human development indicators, like the Human Development Index (HDI).

\section{The Quality of Institutions}

Another important factor that may influence the effect of government size on economic growth is the quality of the political system. For example, Guseh (1997) provided a model that distinguishes the impact of government size on long-term growth across political institutions and argued that the negative effect of the government size on economic growth is three times greater in autocratic regimes compared to the effects in democracies.

Economic theory suggests that government expenditures should increase up to the point where their marginal benefits equal the marginal cost of taxation required for financing them. Better political system institutions would affect both these determinants. Gray et al. (2007) presented a simple analytical framework on how institutional quality affects the relationship between government expenditure and economic growth, as portrayed in Figure 2. Point $A$ presents the intersection of the marginal benefits and marginal cost of a government expansion and depicts the optimal size of government for a typical country, with average quality of institutions.

In countries with better institutions, the marginal benefit of government spending would increase due to better program design and improved management of resources. Moreover, on the taxation side, the marginal cost would decrease due to improved tax design and administration that would confine the distorting effects of raising tax revenues. Thus, in countries with better governance quality, the optimal size of government expenditure and taxes could increase to point $A^{*}$ and eventually an expansion of government expenditure would not deter economic growth. On the other hand if the typical country opted to increase government size to the levels indicated by $E^{*}$ and $T^{*}$, it would result to the creation of a dead-weight loss, captured by the area ABC. Empirical results in Gray et al. (2007) support this negative relationship of government expenditure and economic growth in countries with weak institutions, but beyond a certain level of spending.

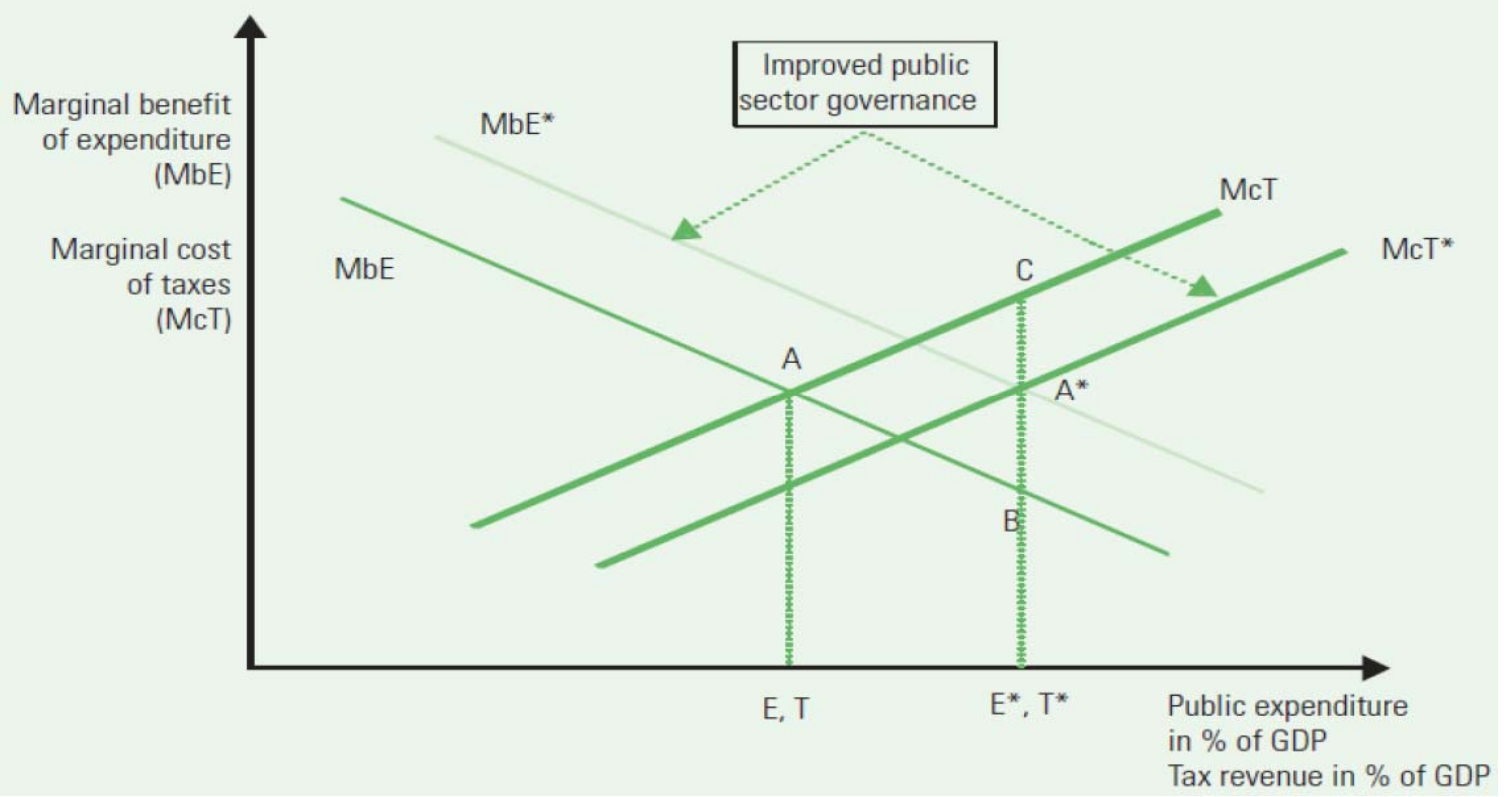

Figure 2: The influence of governance quality on the effect of government size on growth.

Source: Gray et al. (2007, p. 81). 


\section{Methodological Issues}

Bergh and Henrekson (2011) have pointed out the main methodological issues in estimating the relationship between fiscal policy and economic growth $^{4}$. The most important methodological concern in empirical studies that attempt to estimate the effect of government size on economic growth is to properly indicate causation from fiscal policy to growth (Bergh and Henrekson, 2011). As already mentioned, there is empirical evidence that supports Wagner's law of government size being positively associated with economic growth. On the other hand, in times of greater growth rates, unemployment falls and government expenditure is lower. Therefore, the estimated effect of government expenditure on economic growth is highly dependent on the set of countries taken into consideration in the analysis and the time period examined. Already in 1986, Saunders pointed out that cross-country evidence was not robust to the use of different measure of government size, alternate time periods and different groups of countries included in the analysis.

Related to the above, the estimation of a positive or negative effect of government expenditure on economic growth indicates correlation but does not necessarily imply causality from fiscal policy to growth. On the other hand, a negative coefficient on taxes actually provides strong evidence that high taxes deter economic growth, since reverse causality implies a positive correlation in this case (Bergh and Karlsson, 2010). The most commonly used method to overcome this shortcoming is employment of instrumental variables methods. Folster and Henrekson (2001) applied the two stage least squares (2SLS) method where the government expenditure and taxes were instrumented by their lagged levels, and also by fixed country effects, levels and differences of the population and initial GDP variables. This study confirmed the existence of a negative relationship between government size and economic growth.

In a related study, Afonso and Furceri (2010) instrumented government expenditure and tax revenues by their lagged values, trade openness and country population and reported that the magnitude of the negative effect of government size on long-term growth decreases to some extent in EU the OECD countries. Finally, an alternative method is the use of

\footnotetext{
${ }^{4}$ This section is based on the discussion in Bergh and Henrekson (2011).
}

the Generalized Method of Moments (GMM) that employs predetermined and exogenous variables as instruments in a systematic way. This method was applied by Romero-Avila and Strauch (2008) who found a significant negative of government consumption and social transfers on long-term growth, and a small, but significant, positive effect of government investments on growth.

The lack of good instruments for government size, however, means the issue has not yet been completely solved (Bergh and Henrekson, 2011). Bergh and Karlsson (2010) showed that certain tax credits and deductions are correlated with government size, but not with economic growth, thus they could be used appropriately as instruments. However, given that detailed data on deductions and tax credits are available only from 1996 onwards, it will take a number of years before a reasonably long time series can be constructed (Bergh and Henrekson, 2011).

\section{FISCAL POLICY AND SHORT-RUN BUSINESS CYCLES}

\subsection{Theoretical Models}

\subsubsection{The Classical Model}

In the standard classical model, markets are perfectly competitive and prices, real wages and interest rates are flexible. Therefore, the market mechanism guarantees the production of goods at the level of full employment and the aggregate supply curve is vertical, i.e. inelastic to nominal values like the level of prices.

These assumptions have important implications on the effectiveness of fiscal policies that aim to stimulate demand (Demopoulos, 1998). Policy makers could implement policies that would shift aggregate demand, however these would have no effect on employment and output and thus, fiscal policy cannot be considered a stabilization tool. In particular, an increase in public spending, financed by a deficit or borrowing, will increase demand of funds and hence raise interest rates, which will eventually reduce private consumption and investment of the private sector. This crowding-out of the private sector will counterbalance any positive effects of the implemented policy and thus fiscal policy has no net effect on the economy's short-run performance.

\subsubsection{The Keynesian Model}

Keynesian theory assumes short-run rigidity of prices while individuals experience money illusion, 
since there is no distinction between real and nominal values. As a result, there are unused production factors and there is a sizeable rate of unemployment. The aggregate supply curve is determined by the conditions of the non-competitive labour market and is fully elastic in the short-run at the level of the rigid price level, while it is vertical, i.e. inelastic to prices, in the long-run at the level of full employment.

In this model, the determinants of aggregate demand, including fiscal policy, can significantly affect output and employment. The total effect of an increase in government expenditure depends on the relevant magnitude of the multiplier and crowding-out effects (Mankiw, 2000). The multiplier effect is related to the additional shifts in aggregate demand that result when expansionary fiscal policy increases income and thereby increases consumer spending. On the other hand, the crowding-effect is related to the offset in aggregate demand that results when expansionary fiscal policy raises the interest rate and thereby reduces investment spending. Concerning the effects of a tax-cut policy, these also depend on the relative size of the multiplier and crowding out effects. In particular, tax-cuts increase consumers' disposable income and therefore shift aggregate demand. Consequently, higher income leads to greater money demand, which eventually increases the interest rates and reduces private investment. Finally, it should be mentioned, that the Keynesian model predicts a greater enhancing effect of an increase in government expenditure on output and employment, compared to the effect of tax-cuts.

\subsubsection{The Neoclassical Model}

In the neoclassical model, nominal wages and prices are flexible, whilst workers are not influenced by money illusion. In particular, workers predict the price level at each period and adapt their expectations at the real level of prices $\left(P=P^{e}\right)$, claiming respective increases of their wages. Short-run discrepancies between the real and the expected levels of prices can affect the level of equilibrium output and therefore the aggregate supply curve has a positive slope in the short-run.

$\mathrm{Y}=\mathrm{Y}_{\mathrm{F}}+\mathrm{a}^{*}\left(\mathrm{P}-\mathrm{P}^{\mathrm{e}}\right)$, with $\mathrm{a}>0$

If $P^{e}<P$, then $Y>Y_{F}$ and if $P^{e}>P$, then $Y<Y_{F}$

All markets, including the labour market, are fully competitive and lead to full-employment equilibrium. Hence, the long-run aggregate supply curve is vertical, i.e. fully inelastic to the prices level. Moreover, real wages adapt instantaneously and the return to long-run equilibrium occurs rapidly, therefore fiscal policy is not particularly important for the stabilization of the economy.

The neoclassical model, developed mainly in works by Lucas, Sargent and Wallace ${ }^{5}$, has been used extensively for the analysis of fiscal policy. Furthermore, significant contributions and clarifications to the neoclassical model were provided by Aiyagari et al. (1992) and by Baxter and King (1993). In this model an expansion of government expenditure should inevitably be accompanied by an equivalent rise in taxation to satisfy the intertemporal government budget constraint. Perotti (2007) identifies three main forms of fiscal expenditure expansion, namely a temporary expansion financed by lump-sum taxes, a permanent expansion financed by lump-sum taxes and a temporary increase of spending financed by distortionary taxes. In all cases, there is a negative wealth effect on individuals who reduce private consumption and increase labour supply in order to counterbalance the negative effect on their permanent income. The intertemporal substitution in labour supply is crucial for the magnitude of the fiscal multiplier. The increase of labour supply increases output and reduces the real wages. Considering that the capital/labour ratio remains the same, since it is determined uniquely by the rate of time preference, there is a boost in total investment due to the higher desirable level of capital of the economy. The aforementioned effects are relatively greater in magnitude in the case of government spending financed by distortionary taxes, followed by the case of a permanent expansion of expenditure based on lump-sum taxes, while the smaller changes occur in the case of a temporary increase in fiscal spending.

\subsubsection{Neo-Keynesian Models}

In neo-Keynesian models the assumption of money illusion is not central, as is in standard Keynesian theory, albeit due to contracts of employment and other institutional factors of the economy there are price and wage rigidities (Erceg et al., 2000; Christiano et al. 2005) or price rigidities and wage flexibility (Goodfriend and King, 1997). In addition, workers do not have perfect foresight regarding future prices and economic activity fluctuations due to incomplete information. The

\footnotetext{
${ }^{5}$ See, for example, Lucas (1981) and Lucas and Sargent (1981).
} 
aggregate supply curve in these models is more elastic than its counterpart in the neoclassical model and following the implementation of fiscal policy that shifts aggregate demand, the level of output may fluctuate more in the short-run.

In neo-Keynesian models a productivity shock is not a prerequisite of shifting out aggregate demand for labour and this can be achieved by other shocks including a fiscal policy expansion. According to the strength of the shift of labour demand, the real wage can increase and eventually cause a higher consumption, either through a substitution or credit constraint effect. In particular, Perotti (2007) classifies neo-Keynesian models into the following three categories, according to the mechanisms that government spending shocks increase real wages:

\section{Countercyclical Mark-Ups}

A positive demand shock leads output and marginal cost to increase and because prices cannot adjust immediately, the mark-up falls. For example, Rotemberg and Woodford (1992) suggest that a government spending expansion increases current demand compared to future demand and thus amplifies incentives to undercut collusive pricing between oligopolistic firms.

\section{Nominal Rigidities}

In order to meet increased demand caused by a government spending shock, firms supply more output and therefore labour demand and output rises, while real wages increase despite the shift in labour supply (Linnemann and Schabert, 2003). However, it should be highlighted that the nature of rigidity matters since, in the case of wage rigidities, the real wage might decrease following a government spending shock.

\section{$\underline{\text { Increasing Returns }}$}

In Devereux et al. (1996) and Bilbiie et al. (2005) a government spending shock increases the equilibrium number of firms in the intermediate good sectors, which are characterized by increasing returns to specialization. Consequently, the productivity in these sectors increases and thus a higher real wage is achieved, despite the negative wealth effect on labour supply.

Following the rise in real wages, there are two mechanisms through which a rise in consumption may occur. Firstly, individuals with higher real wages tend to substitute leisure with consumption, therefore increasing private consumption (Devereux et al., 1996; Ravn et al. 2006). However, in models with nominal rigidities the increase in the real wage may not be enough to lead to an increase in consumption, which may be achieved by a second route through the introduction of credit constraints in the model (Gali et al., 2007).

\subsection{Empirical Literature Review}

Macroeconomic theory and particularly Keynesian models provide several practical insights to policy makers on how to implement fiscal policy to alleviate the adversary effects of business cycle fluctuations. A growing body of empirical works, based on time series econometrics methods relying on minimal assumptions and a priori theory, has tested the validity of these theoretical insights. Nevertheless, the related literature does not provide unanimous evidence on the mechanisms through which fiscal policy may affect economic activity and the findings are highly dependent on the econometric approach employed. Following Caldara and Kamps (2008) we may categorize this strand of literature, based on the econometric approach used to identify fiscal policy shocks, as follows:

\section{Recursive Approach}

This approach implies a causal ordering of the model variables and relies on Cholesky decomposition to identify fiscal policy shocks. Therefore, in this method, the ordering of the variables is crucial and should rely on viable and testable assumptions. Fatas and Mihov (2001) used this method and reported a government spending multiplier greater than one. Moreover, they found that this increase of output is associated with an increase in private consumption, while investment is not significantly affected. These findings are in line with the Keynesian model.

\section{Structural VAR Approach}

Blanchard and Perotti (2002) proposed a two-step method to identify fiscal policy shocks. In the first step, institutional information regarding tax and transfer systems, as well as their timing, are used to isolate the automatic responses of government expenditure and taxes to the business cycle, therefore allowing estimation of the fiscal policy shocks in the second step. Their findings suggest that government spending reinforces output, private consumption and real wages, consistent with Keynesian theory. On the other hand, they also reported that both increases in government expenditure and taxes have a significant negative 
relationship with private investment ${ }^{6}$. This finding reconciles with the neoclassical model but is not consistent with Keynesian models, which, although agnostic about the sign of these effects, predict opposite qualitative effects of spending and taxes on private investment. Related studies, with findings that are consistent with Keynesian theory, include Perotti (2007) and Fragetta and Melina (2010).

\section{Sign Restrictions Approach}

The sign restrictions approach was introduced by Faust (1998) in order to examine the effect of monetary policy. This method identifies policy shocks by imposing sign restriction on the impulse responses but does not impose any restrictions on the signs of the responses of the key variables of interest to fiscal policy shocks. Mountford and Uhlig (2009) applied this approach to examine the effects of fiscal policy on economic activity in the U.S. and found that a surprise deficit-financed tax cut is the best fiscal policy to stimulate the economy, while a deficit-financed government spending shock only weakly stimulates the economy. Moreover, they reported that government spending shocks crowd-out residential and nonresidential investment without making interest rates to increase. These findings are not consistent with standard Keynesian theory, according to which government expenditure multipliers are greater than tax multipliers and crowding-out is caused by an increase in taxes ${ }^{7}$.

\section{Event-Study Approach}

In order to identify macroeconomic policy shocks, Ramey and Shapiro (1998) looked for fiscal episodes which can be considered exogenous with respect to the state of the economy. The majority of the studies using this approach contemplate the effects of defence expenditure increases, since this category can be considered exogenous when related to spending associated with wars or unexpected military build-ups (Perotti, 2007; Ramey, 2011). The aforementioned studies report that an increase in defence expenditure stimulates output, while it reduces real wages and consumption.

\footnotetext{
${ }^{6}$ For a similar finding regarding the effect of government expenditure on private investment see Alesina et al. (1999) and Alesina and Ardagna (2010).

${ }^{7}$ The finding that the tax multiplier is greater than the government expenditure multiplier is reported in a growing number of recent studies. For example, Ramey (2011) reported that the government expenditure multiplier in the U.S. economy is 1.4, while in a related study Romer and Romer (2009) found that a reduction of tax revenues by $\$ 1$ increases GDP by $\$ 3$. Contrary to that, according to the January 2009 Council of Economic Advisers of the U.S. government, an extra dollar of government spending raises GDP by $\$ 1.57$, while a dollar of tax cuts raises GDP by only 99 cents (Mankiw, 2009).
}

\section{CONCLUSIONS AND FUTURE RESEARCH DIRECTIONS}

The empirical evidence in the literature regarding the relationship between government size and economic growth remains indeterminate. As Angelopoulos et al. (2008) point out this ambiguity may be attributed to the omission from the analysis of several elements that shape the government sizegrowth relationship, such as the efficiency of the public sector. Therefore, future research on this relationship should consider in more detail such interrelationships. A limitation in this field is the lack of data on the composition of government expenditure for a large sample of countries and for a long period of time.

In addition, it is likely that the size of government expenditure and its composition are associated with key aspects of the quality of growth, such as income inequality and environmental sustainability (Lopez et al., 2010; Halkos and Paizanos, 2015). For example, Halkos and Paizanos (2013) have argued that in order to capture the total effect of government expenditure on the environment, the analysis should be conducted in a joint framework with two other bodies of literature, namely the literature linking fiscal policy to economic performance, as well as the literature on the growthpollution relationship.

In the literature there is a lack of theoretical models that examine the underpinnings of the relationship between fiscal policy, output and aspects of growth quality such as the level of environmental degradation; however, for the establishment of such models, the results occurring from recent works can provide a useful starting point (Lopez et al, 2011; Halkos and Paizanos, 2013; Galinato and Islam, 2014).

\section{ACKNOWLEDGEMENT}

This research has been co-financed by the European Union (European Social Fund - ESF) and Greek national funds through the Operational Program "Education and Lifelong Learning" of the National Strategic Reference Framework (NSRF) - Research Funding Program: Heracleitus II. Investing in knowledge society through the European Social Fund.

\section{REFERENCES}

Acemoglu D., Johnson S. and Robinson J.A. (2002). Reversal of Fortune: Geography And Institutions In The Making Of The Modern World Income Distribution, The Quarterly Journal Of Economics, MIT Press, 117(4), 1231-1294. 
Adam C. and Bevan D.L. (2005). Fiscal Deficits and Growth in Developing Countries, Journal of Public Economics, 89 (4), 571-97.

http://dx.doi.org/10.1016/j.jpubeco.2004.02.006

Afonso A. and Furceri D. (2010). Government Size, Composition, Volatility and Economic Growth. European Journal of Political Economy, 26 (4), 517-532.

http://dx.doi.org/10.1016/j.ejpoleco.2010.02.002

Agénor P. R. and Neanidis K.C. (2006). The Allocation of Public Expenditure and Economic Growth, Centre for Growth and Business Cycle Research Discussion Paper Series No. 69, University of Manchester.

Alesina A., Ardagna S., Perotti R. and Schiantarelli F. (1999). Fiscal policy, profits, and investment, NBER Working Papers No 7207, National Bureau of Economic Research, Inc.

Alesina A. and Ardagna S. (2010). Large Changes in Fiscal Policy: Taxes versus Spending, National Bureau of Economic Research, NBER Chapters, in: Tax Policy and the Economy, 24, 35-68

http://dx.doi.org/10.1086/649828

Angelopoulos K., Philippopoulos A. and Tsionas M. (2008). Does public sector efficiency matter ?: revisiting the relation between fiscal size and economic growth in a world sample, Public Choice, 137(1-2), 245-278. http://dx.doi.org/10.1007/s11127-008-9324-8

Armey D. (1995). The Freedom Revolution, Regnery Publishing, Washington, DC.

Aschauer D.A. (1988). The Equilibrium Approach to Fiscal Policy, Journal of Money, Credit and Banking, Blackwell Publishing, 20 (1), 41-62.

Aschauer D. A. (1989). Is public expenditure productive?, Journal of Monetary Economics, Elsevier, 23 (2), 177-200. http://dx.doi.org/10.1016/0304-3932(89)90047-0

Åslund A. and Jenish N. (2006). The Eurasian Growth Paradox. Working Paper Series WP06-5, Peterson Institute for International Economics. http://dx.doi.org/10.2139/ssrn.911661

Aiyagari S., Lawrence J.C. and Eichenbaum M. (1992). The output, employment, and interest rate effects of government consumption, Journal of Monetary Economics, 30 (1), 73-86. http://dx.doi.org/10.1016/0304-3932(92)90045-4

Bajo-Rubio O. (2000). A further generalization of the Solow growth model: the role of the public sector, Economic Letters, 68, 79-84. http://dx.doi.org/10.1016/S0165-1765(00)00220-2

Baier S.L. and Glomm G. (2001). Long-run growth and welfare effects of public policies with distortionary taxation, Journal of Economic Dynamics and Control, Elsevier, 25(12), 20072042. http://dx.doi.org/10.1016/S0165-1889(00)00017-8

Barro R. J. (1990). Government Spending in a Simple Model of Endogenous Growth, Journal Of Political Economy, 98 (5 part 2), 103-125. http://dx.doi.org/10.1086/261726

Barro R.J. (1991). Economic Growth in a Cross Section of Countries, The Quarterly Journal of Economics, 106(2), 407-443. http://dx.doi.org/10.2307/2937943

Barro R. J. (2001). Human Capital and Growth, American Economic Review, 91(2), 12-17. http://dx.doi.org/10.1257/aer.91.2.12

Barth J.R. and Bradley M.D. (1987). The Impact of Government Spending on Economic Activity, George Washington University Manuscript.

Baxter M. and King R. (1993). Fiscal Policy in General Equilibrium, American Economic Review, 83, 315-334.

Beck T. and Laeven L.A. (2005). Institution Building and Growth in Transition Economies, Policy Research Working Paper No. 3657, World Bank, Washington, DC.
Berggren N. and Henrik J. (2005). Does Free Trade Really Reduce Growth? Further Testing Using the Economic Freedom Index, Public Choice, 122 (1-2), 99-114. http://dx.doi.org/10.1007/s11127-005-3994-2

Bergh A. and Karlsson M. (2010). Government size and growth: Accounting for economic freedom and globalization, Public Choice, 142 (1), 195-213. http://dx.doi.org/10.1007/s11127-009-9484-1

Bergh A. and Henrekson M. (2011). Government Size and Growth: a survey and interpretation of the evidence, Journal of Economic Surveys, 25, 872-897. http://dx.doi.org/10.1111/j.1467-6419.2011.00697.x

Bergh A. and Öhrn N. (2011). Growth Effects of Fiscal Policies: A Critique of Colombier, Mimeo, Stockholm, Research Institute of Industrial Economics.

Besley T. and Persson T. (2009). The Origins of State Capacity: Property Rights, Taxation, and Policy, American Economic Review 99(4), 1218-1244. http://dx.doi.org/10.1257/aer.99.4.1218

Bilbiie F.O., Ghironi F. and Melitz M.J. (2005). "Business Cycles and Firm Dynamics", Society for Economic Dynamics, 2005 Meeting Papers.

Blanchard O.J. and Perotti R. (2002). An Empirical Characterization of the Dynamic Effects of Changes in Government Spending and Taxes on Output, Quarterly Journal of Economics, 117 (4), 1329-1368. http://dx.doi.org/10.1162/003355302320935043

Bleaney M., Gemmell N. and Kneller R. (2001). Testing the Endogenous Growth Model: Public Expenditure, Taxation and Growth over the Long-Run, Canadian Journal of Economics, 34, 36-57. http://dx.doi.org/10.1111/0008-4085.00061

Browning E.K. (1976). The Marginal Cost of Public Funds, Journal of Political Economy, 84, 283-298. http://dx.doi.org/10.1086/260432

Buchanan J. M. (1980). Rent-Seeking and Profit-Seeking, In James M. Buchanan, Tollison R.D. and Tullock G. eds., Toward a Theory of the Rent-Seeking Society, College Station, TX: Texas A\&M University Press, pp. 3-15.

Caldara D. and Kamps C. (2008). What are the Effects of Fiscal Policy Shocks? A VAR-based Comparative Analysis, ECB Working Paper No. 877, European Central Bank, Frankfurt/Main

Cameron D. (1982). On the Limits of the Public Economy, Annals of the Academy of Political and Social Science, 459(1), 46-62. http://dx.doi.org/10.1177/0002716282459001004

Campos N.F. and Coricelli F. (2002). Growth in Transition: What We Know, What We Don't, and What We Should, Journal of Economic Literature, 40(3), 793-836. http://dx.doi.org/10.1257/jel.40.3.793

Cass D. (1965). Optimum Growth in an Aggregative Model of Capita Accumulation, Review of Economic Studies, 32(3), 233-240. http://dx.doi.org/10.2307/2295827

Chen B.-L. and Lu C.-H. (2013). Optimal factor tax incidence in twosector human capital-based models, Journal of Public Economics, Elsevier, 97(C), 75-94. http://dx.doi.org/10.1016/j.jpubeco.2012.09.008

Chen S.-T. and Lee C.-C. (2005). Government size and economic growth in Taiwan: A threshold regression approach, Journal of Policy Modeling, Elsevier, 27(9), 1051-1066. http://dx.doi.org/10.1016/j.jpolmod.2005.06.006

Chobanov D. and Mladenova A. (2009). What Is the Optimum Size of Government, Institute for Market Economics, August 2009.

Christiano L.J., Eichenbaum M. and Vigfusson R. (2005). Assessing Structural VARs, NBER Macroeconomics Annual, 21, 1-106. http://dx.doi.org/10.1086/ma.21.25554953 
Colombier C. (2009). Growth Effects of Fiscal Policies: An Application of Robust Modified M-Estimator, Applied Economics, 41(7), 899-912. http://dx.doi.org/10.1080/00036840701736099

Dalamagas B. (2000). Public sector and economic growth: the Greek experience", Applied Economics, 32, 277-288. http://dx.doi.org/10.1080/000368400322705

Davies A. (2008). Human Development and the Optimal Size of Government, Journal of Socioeconomics, 38(2009), 326330

Dawson J.W. (2003). Causality in the Freedom-Growth Relationship, European Journal of Political Economy, 19, 479-495. http://dx.doi.org/10.1016/S0176-2680(03)00009-0

Demopoulos G.D. (1998). Macroeconomic Theory, Athens.

Devarajan S. V., Swaroop V. and Zou H. (1996). The Composition of Public Expenditure and Economic Growth, Journal of Monetary Economics, 37, 313-344. http://dx.doi.org/10.1016/S0304-3932(96)90039-2

Devereux M. and Love D. (1994). The Effects of Factor Taxation in a Two-Sector Model of Endogenous Growth, The Canadian Journal of Economics, 27(3), 509-536. http://dx.doi.org/10.2307/135781

Devereux M.B., Head A.C. and Lapham B.J. (1996). "Monopolistic Competition, Increasing

Devereux M.B., Head A.C. and Lapham B.J. (1996). "Monopolistic Competition, Increasing Returns, and the Effects of Government Spending", Journal of Money, Credit and Banking, 28(2), 233-254. http://dx.doi.org/10.2307/2078025

Returns, and the Effects of Government Spending", Journal of Money, Credit and Banking, 28(2), 233-254. http://dx.doi.org/10.2307/2078025

Dowrick S. (1993). Government Consumption: Its Effects on Productivity Growth and Investment. In: N. Gemmell, ed. The Growth off the Public Sector: Theories and International Evidence. Aldershot: Edward Elgar.

Easterly W. and Rebelo S. (1993a). Marginal Income Tax Rates and Economic Growth in Developing Countries, European Economic Review, 37(2-3), 409-417. http://dx.doi.org/10.1016/0014-2921(93)90029-A

Easterly W. and Rebelo S. (1993b). Fiscal Policy and Economic Growth, Journal of Monetary Economics, 32, 417-458. http://dx.doi.org/10.1016/0304-3932(93)90025-B

Engen E.M. and Skinner J. (1992). Fiscal Policy and Economic Growth, NBER Working Papers No 4223.

Erceg C.J., Bordo M.D., Evans C.L. (2000). Money, Sticky Wages, and the Great Depression, American Economic Review, American Economic Association, 90(5), 1447-1463. http://dx.doi.org/10.1257/aer.90.5.1447

Fatás A. and Mihov I. (2001). The Effects of Fiscal Policy on Consumption and Employment: Theory and Evidence, CEPR Discussion Paper 2760, London.

Fatás A. and Mihov I. (2003). The Case for Restricting Fiscal Policy Discretion, Quarterly Journal of Economics, 118, 1419-1447. http://dx.doi.org/10.1162/003355303322552838

Faust J. (1998). The Robustness of Identified VAR Conclusions about Money, Carnegie-Rochester Conference Series on Public Policy, 49, 207-244.

Fisher S. (1993). The role of Macroeconomic factors in growth. Journal of Monetary Economics, 32, 485-512. http://dx.doi.org/10.1016/0304-3932(93)90027-D

Fölster S. and Henrekson M. (2001). Growth Effects of Government Expenditure and Taxation in Rich Countries, European Economic Review, 45 (8), 1501-1520.

Fragetta M. and Melina G. (2010). The Effects of Fiscal Shocks in SVAR Models: A Graphical Modelling Approach, Birkbeck Working Papers in Economics and Finance 1006, Birkbeck, Department of Economics, Mathematics \& Statistics.
Galí J., López-Salido J.D. and Vallès J. (2007). Understanding the effects of government spending on consumption. Journal of the European Economic Association, 5(1), 227-270. http://dx.doi.org/10.1162/JEEA.2007.5.1.227

Galinato G.I and Islam F. (2014). The Challenge of Addressing Consumption Pollutants with Fiscal Policy, Working Paper Series WP 2014-1, Washington State University, Washington.

Ghali K.H. (1998). Government size and economic growth: evidence from a multivariate cointegration analysis, Applied Economics, 31, 975-987.

Glaeser E.L., La Porta R., Lopez-de-Silanes F. and Shleifer A. (2004). Do Institutions Cause Growth? Journal of Economic Growth, 9 (3): 271-303.

Glomm G. and Ravikumar B. (1994). Public investment in infrastructure in a simple growth model, Journal of Economic Dynamics and Control, 18, 1173-1187.

Goodfriend M. and King R. (1997). The New Neoclassical Synthesis and the Role of Monetary Policy. NBER Chapters, in: NBER Macroeconomics Annual, National Bureau of Economic Research, Inc., 12, 231-296. http://dx.doi.org/10.1086/654336

Gray C., Lane T. and Varoudakis A. (2007). Fiscal Policy and Economic Growth: Lessons for Eastern Europe and Central Asia, The World Bank.

Grier K.B. and Tullock G. (1989). An Empirical Analysis of CrossNational Economic Growth, 1951-80, Journal of Monetary Economics, 24 (2), 259-276.

Grossman P. (1987). The Optimal Size of Government, Public Choice, 53 (2), 131-147.

Guellec D. and van Pottelsberghe B. (1999). Does Government Support Stimulate Private R\&D? OECD Economic Studies, 29(1997/II), 95-122.

Guseh J.S. (1997). Government size and economic growth in developing countries: a political-economy framework, Journal of Macroeconomics, 19, 175-192.

Gwartney J. and Lawson R. (1997). Economic Freedom of the World: 1997 Annual Report, Fraser Institute, Vancouver, B.C. Canada.

Gwartney J., Lawson R. and Holcombe R. (1998). The size and functions of government and economic growth, Joint Economic Committee, Washington, D.C., April.

Halkos G.E. and Paizanos E. (2013). The effect of government expenditure on the environment: An empirical investigation, Ecological Economics, 91, 48-56.

Halkos G.E. and Paizanos E. (2015). Environmental Macroeconomics: A critical literature review and future empirical research directions, MPRA working paper, No. 67432.

Hansson P. and Henrekson M. (1994). A New Framework for Testing the Effect of Government Spending on Growth and Productivity. Public Choice, 81(3-4), 381-401. http://dx.doi.org/10.1007/BF01053239

International Monetary Fund (IMF - 2015). Fiscal Policy and Longterm Growth, IMF Policy Paper.

Jones C. (2001). Introduction to Economic Growth (Second Edition), W. W. Norton \& Company.

Jones L., Manuelli R. and Rossi P. (1993). Optimal taxation in models of endogenous growth, Journal of Political Economy, 101, 485-517.

King R. and Rebelo S. (1990). Public Policy and Economic Growth: Developing Neoclassical Implications, Journal of Political Economy, 98(5), 126-150.

Kneller, R., Bleaney M. and Gemmell N. (1999). Public Policy and the Government Budget Constraint: Evidence from the OECD, Journal of Public Economics, 74, 171-190. 
Koester R. B. and Kormendi R. (1989). Taxation, Aggregate Activity and Economic Growth: Cross-Country Evidence on Some Supply-Side Hypotheses, Economic Inquiry, 27, 367-386.

Kollias C., Mylonidis N. and Paleologou S-M. (2007). A Panel Data Analysis Of The Nexus Between Defence Spending And Growth In The European Union, Defence and Peace Economics, Taylor \& Francis Journals, 18(1), 75-85.

Kollias C. and Paleologou S-M. (2010). Growth, investment and military expenditure in the European Union-15, Journal of Economic Studies, 37(2), $228-240$.

Koopmans C. (1965). On the concept of optimal economic growth, in (Study Week on the) Econometric Approach to Development Planning, chap. 4, pp. 225-87. North-Holland Publishing Co., Amsterdam.

Kormendi R. and Meguire P.C. (1985). Macroeconomic determinants of growth: Cross country evidence, Journal of Monetary Economics, 16, 141-163.

Landau D. (1983). Government Expenditures and Economic Growth: A Cross-Country Study, Southern Economic Journal, 49, 783-792.

Landau D. (1986). Government and Economic Growth in the Less Developed Countries: An Empirical Study for 1960-1980, Economic Development and Cultural Change, 35(1), 35-75.

Lane P. (2003). The Cyclical Behavior of Fiscal Policy: Evidence from the OECD, Journal of Public Economics, 87, 22612275.

Lee Y. and Gordon R.H. (2005). Tax structure and economic growth, Journal of Public Economics, 89, 1027-1043.

Levine R. and Renelt D. (1992). A Sensitivity Analysis of CrossCountry Growth Regressions, American Economic Review, 82(4), 942-963.

Linnemann L. and Schabert A. (2003). Fiscal Policy in the New Neoclassical Synthesis, Journal of Money Credit and Banking, 35(6), 911-929.

Lopez R., Galinato G.I and Islam F. (2011). Fiscal spending and the environment: Theory and empirics, Journal of Environmental Economics and Management, 62, 180-198.

Lopez R., Thomas V. and Wang Y. (2010). The Quality of Growth: Fiscal Policies for Better Results, IEG World Bank.

Lucas R.E. Jr. (1981). Studies in Business Cycle Theory, Blackwell, Oxford.

Lucas R.E. Jr. and Sargent T.J. (1981). Rational Expectations and Econometric Practice, Allen and Unwin, London.

Lucas R.E. Jr. (1988). On the Mechanics of Development Planning, Journal of Monetary Economics, 22, 3-42.

Lucas R.E. Jr. (1990). Supply-Side Economics: An Analytical Review, Oxford Economic Papers, Oxford University Press, 42 (2), 293-316.

Mankiw G., Romer D. and Weil D. (1992). A Contribution to the Empirics of Economic Growth, The Quarterly Journal of Economics, 107(2), 407-437.

Mankiw G. (2000). Macroeconomics, 4th edition.

Mankiw N.G. (2009). Tax Cuts Might Accomplish What Spending Hasn't, New York Times, December 13, 2009.

Marlow M.L. (1986). Private Sector Shrinkage and the Growth of Industrialized Economies, Public Choice, 49(2), 143-154.

Miller S. and Russek F. (1997). Fiscal Structures and Economic Growth: International Evidence, Economic Inquiry, 35, 603613.

Mountford A. and Uhlig H. (2009). What are the Effects of Fiscal Policy Shocks? Journal of Applied Econometrics, 24, 960992.

Nelson M.A., and Singh R.D. (1998). Democracy, Economic Freedom, Fiscal Policy, and Growth in LDCs: A Fresh Look, Economic Development and Cultural Change, 46(3), 677-96.
North D.C. (1987). Institutions, Transaction Costs and Economic Growth. Economic Inquiry, 25(3), 419-428. http://dx.doi.org/10.1111/j.1465-7295.1987.tb00750.x

North D.C. (1991). Institutions, Journal of Economic Perspectives, American Economic Association, vol. 5(1), 97-112.

Nourzad F. and Vrieze M. (1995). Public Capital Formation and Productivity Growth: Some International Evidence, Journal of Productivity Analysis, 6(4): 283-95.

Olson M. (1982). The Rise and Decline of Nations: Economic Growth, Stagflation, and Social Rigidities, Yale University Press, New Haven, CN.

Organization for Economic Co-operation and Development (OECD 2011). The Impact of the 1999 Education Reform in Poland, OECD Education Working Papers, No. 49.

Padovano F. and Galli E. (2002)a. Comparing the Growth Effects of Marginal vs. Average Tax Rates and Progressivity, European Journal of Political Economy, 18 (30), 529-44.

Padovano F. and Galli E. (2002)b. Tax Rates and Economic Growth in the OECD Countries (1950-1990), Economic Inquiry, 39 (1), 44-57.

Pecorino P. (1993). Tax structure and growth in a model with human capital, Journal of Public Economics, 52, 251-271. http://dx.doi.org/10.1016/0047-2727(93)90023-M

Peden E.A. (1991). Productivity in the United States and Its Relationship to Government Activity: An Analysis of 57 Years, 1929-1986, Public Choice, 69, 153-173. http://dx.doi.org/10.1007/BF00123845

Perotti R. (2007). In Search of the Transmission Mechanism of Fiscal policy, NBER Macroeconomics Annual, 22, 169-226.

Psarianos I.N. (2002). Fiscal Policy in an Endogenous Growth Model with Horizontally Differentiated Intermediate Goods. Spoudai, 52(4), 18-41.

Psarianos I.N. (2009). Lecture notes on Economic Growth. University of Thessaly.

Quah D.T. (1996). Empirics for Economic Growth and Convergence, European Economic Review, 40, 1353-1375. http://dx.doi.org/10.1016/0014-2921(95)00051-8

Ram R. (1986). Government size and economic growth: A new framework and some evidence from cross section and TimeSeries Data, American Economic Review, 76, 191-203.

Ram R. (1989). Government Size and Economic Growth: A New Framework and Some Evidence from Cross-Section and Time-Series Data: Reply, American Economic Review, 79, 281-284.

Ramey V.A. and Shapiro M.D. (1998). Costly Capital Reallocation and the Effects of Government Spending, CarnegieRochester Conference Series on Public Policy, 48, 145-194. http://dx.doi.org/10.1016/S0167-2231(98)00020-7

Ramey V.A. (2011). Can Government Purchases Stimulate the Economy?. Journal of Economic Literature, American Economic Association. 49 (3), 673-85. http://dx.doi.org/10.1257/jel.49.3.673

Ravn M., Schmitt-Grohé S. and Uribe M. (2006). Deep Habits. Review of Economic Studies, 73(1), 195-218. http://dx.doi.org/10.1111/j.1467-937X.2006.00374.x

Rebelo S.T. (1991). Long-Run Policy Analysis and Long-Run Growth, Journal of Political Economy, 99(3), 500-521. http://dx.doi.org/10.1086/261764

Rodrik D., Subramanian A. and Trebbi F. (2004). Institutions Rule: The Primacy of Institutions over Geography and Integration in Economic Development, Journal of Economic Growth, 9(2), 131-165. http://dx.doi.org/10.1023/B:JOEG.0000031425.72248.85

Romer C. D. and Romer D. H. (2009). Do Tax Cuts Starve the Beast? The Effect of tax Changes on Government Spending, Brookings papers on economic activity, 40(1), 139-214. http://dx.doi.org/10.1353/eca.0.0046 
Romer P. (1990). Endogenous Technological Change, Journal of Political Economy, 98 (5), 71-102. http://dx.doi.org/10.1086/261725

Romer P.M. (1986). Increasing Returns and Long-Run Growth, Journal of Political Economy, 94, October, 1002-1037. http://dx.doi.org/10.1086/261420

Romero-Avila D. and Strauch R. (2008). Public Finances and LongTerm Growth in Europe: Evidence from a Panel Data Analysis, European Journal of Political Economy 24(1): 172191.

http://dx.doi.org/10.1016/j.ejpoleco.2007.06.008

Rotemberg J. and Woodford M. (1992). Oligopolistic pricing and the effects of aggregate demand on economic activity, Journal of Political Economy, 110(6), 1153-1207. http://dx.doi.org/10.1086/261857

Sala-i-Martin X. (1997). I Just Ran Two Million Regressions, AEA Papers and Proceedings, 87, 178-183.

Sanchez-Robles B. (1998). Infrastructure Investment and Growth: Some Empirical Evidence, Contemporary Economic Policy, 16 (1), 98-108.

http://dx.doi.org/10.1111/j.1465-7287.1998.tb00504.x

Schumpeter J. A. (1942). Capitalism, Socialism and Democracy, Harper \& Brothers, New York.

Slemrod J. (1995). What Do Cross-Country Studies Teach About Government Involvement, Prosperity, and Economic Growth? Brookings Papers on Economic Activity, 2. http://dx.doi.org/10.2307/2534615

Solow R. M. (1956). A Contribution to the Theory of Economic Growth, Quarterly Journal of Economics, 70(1), 65-94. http://dx.doi.org/10.2307/1884513
Swan T.W. (1956). Economic Growth and Capital Accumulation, Economic Record, 32 (2), 334-361. http://dx.doi.org/10.1111/j.1475-4932.1956.tb00434.x

Tanzi V. and Zee H. (1997). Fiscal policy and long-run growth, IMF Staff Papers, 44, 179-209. http://dx.doi.org/10.2307/3867542

Taylor L., Proaño C.R., de Carvalho L. and Barbosa N. (2011). Fiscal Deficits, Economic Growth, and Government Debt in the USA, Working paper 2011-10, Schwartz Center for Economic Policy Analysis.

Turnovsky S. and Fisher W. (1995). The composition of government expenditure and its consequence for macroeconomic performance, Journal of Economic Dynamics and Control, 19, 747-786. http://dx.doi.org/10.1016/0165-1889(94)00803-P

Turnovsky S. (2000). Fiscal Policy, Elastic Labour supply and Endogenous Growth, Journal of Monetary Economics, 45, 185-210. http://dx.doi.org/10.1016/S0304-3932(99)00047-1

Turnovsky S. (2004). The Transitional Dynamics of Fiscal Policy: Long-Run Capital Accumulation and Growth, Journal of Money, Credit and Banking, 36(5), 883-910. http://dx.doi.org/10.1353/mcb.2004.0069

Widmalm F. (2001). Tax Structure and Growth: Are Some Taxes Better than Others? Public Choice, 107(3-4), 199-219. http://dx.doi.org/10.1023/A:1010340017288

Yohai V., Stahel W.A. and Zamar R.H. (1991). A Procedure for Robust Estimation and Inference in Linear Regression., IMA Volumes in Mathematics and Its Application, Directions in Robust Statistics - Part II, Vol. 34, 365-374. http://dx.doi.org/10.1007/978-1-4612-4444-8 20

\section{DOI: http://dx.doi.org/10.6000/1929-7092.2016.05.01}

(C) 2016 Halkos and Paizanos; Licensee Lifescience Global.

This is an open access article licensed under the terms of the Creative Commons Attribution Non-Commercial License (http://creativecommons.org/licenses/by-nc/3.0/) which permits unrestricted, non-commercial use, distribution and reproduction in any medium, provided the work is properly cited. 